\title{
Hormone van die soogdierhart
}

Tot onlangs is die hart beskou as 'n eenvoudige, maar baie doeltreffende pomp wat die sistemiese sirkulasie met die longsirkulasie skakel en die primêre taak het om die bloed onder hoë druk in die arterieë te pomp vir doeltreffende voorsiening van gasse en voedingstowwe aan, en verwydering van afvalprodukte vanaf die weefselselle. Hierdie simplistiese beskouing het in die lig van navorsing gedurende die afgelope aantal jare verouderd geraak. Dit word nou aanvaar dat die funksie van die soogdierhart veel meer as net dié van 'n meganiese pompsisteem behels. Die hart, en met name die atriumspier, vertoon die tipiese eienskappe van ' $n$ endokriene orgaan - dit is in staat om onder sekere omstandighede peptiede (moontlik ook amiene) te sintetiseer, in granules in atriumselle te stoor en in die bloed te sekreteer om sodoende die funksies van sekere teikenorgane te beïnvloed. Aangesien hierdie granules in die geval van soogdiere slegs in atriumspierselle en nie in die ventrikelspier gevind word nie, word hulle as spesifieke atriumgranules (SAG) beskryf. In laer werweldiere bevat sowel atrium as ventrikel granules. Die redes vir hierdie verskil is egter nog onbekend.

Navorsing oor SAG in die Departement Fisiologie, Universiteit van Pretoria, het in 1978 begin met 'n ondersoek van die ultrastruktuur van die atriumspier by rotte, Rhesusape en bobbejane (Papio ursinus). ${ }^{1}$ Die resultate het bewys dat SAG in sekere opsigte van sekretoriese granules in ander seltipes verskil:

- na prosessering in die Golgikompleks word proteiene afkomstig van reseptorproteiene van die selmembraan deur middel van reseptorbemiddelde endositose in die granulemembraan geinkorporeer (adenosien trifosfatase mag een van hierdie proteiene wees),

- die deel van die granulemembraan afkomstig van die Golgikompleks is besonder labiel, en gevolglike intrasellulère membraanliese met vrystelling van die granule-inhoud in die algemene sitoplasma is waargeneem,

- geen bewyse van eksositose, wat die kenmerkende sekresiemeganisme vir peptiede in ander selle is, kon in SAG gevind word nie.

Verdere navorsing is op die bepaling van die inhoud van SAG toegespits. Sito- en histochemiese metodes wat vir hierdie doel toegepas is, het egter slegs beperkte sukses gelewer, waarskynlik omdat SAG so klein is dat hulle moeilik met behulp van ligmikroskopie gevisualiseer kan word. Aangesien die membrane van SAG so labiel is, is dit ook moeilik om subsellulère fraksies van intakte SAG te berei.
Die gebruik van ru-ekstrakte van die atriumspier en soortgelyke ekstrakte van die ventrikelspier, wat vry is van SAG, het egter die weg gebaan tot die ontdekking van fisiologies-aktiewe bestanddele met kragtige fisiologiese funksies in die atriumspier:

1. In die Departement Fisiologie is aangetoon dat 'n varsbereide ru-ektrak van die atriumspier van bobbejane by toediening aan ' $n$ rotpreparaat, ' $n$ onmiddellike verhoging in bloeddruk ontlok het (pressorrespons, met 'n toename van tot $25 \%$ in gemiddelde bloeddruk). Toediening van soortgelyke ekstrakte van die ventrikelspier het daling in bloeddruk veroorsaak (depressorrespons, met 'n daling van tot $30 \%$ in die gemiddelde bloeddruk). ${ }^{2,3}$ Ons kon bewys dat die ventrikulère depressorreaksie veroorsaak word deur adenien nukleotiede (hoofsaaklik adenosien monofosfaat), wat ook vir depressorreaksies uitgelok deur ander spiertipes, verantwoordelik is. ${ }^{4}$

Weens praktiese oorwegings het ons konynatria vir die karakterisering van metaboliete wat moontlik vir die atriale pressorrespons verantwoordelik mag wees, gebruik. ${ }^{5}$ Deur gebruik te maak van skeidingstegnieke soos jelpermeasie en hoëdrukvloeistofchromatografie, kon ons daarin slaag om 'n gedeeltelik gesuiwerde produk uit konynatriumspier te isoleer. Dit moet beklemtoon word dat hierdie produk geen natriuretiese, diuretiese en vaatverslappende aktiwiteite vertoon het nie (sien 2 hieronder), maar die potente pressoraktiwiteit is steeds behou. Die pressoraktiwiteit het egter verdwyn na blootstelling aan die proteolitiese ensiem Pronase- $\mathrm{CB}^{\mathrm{TH}}$. Hierdie e.a. resultate het gelei tot die gevolgtrekking dat die pressoraktiwiteit van die atriumspier toegeskryf kan word aan 'n peptied met molekulêre massa van ongeveer 900 dalton, wat ons atriotonien (AT) gedoop het.

Die aminosuurvolgorde van atriotonien kon nog nie bepaal word nie, maar dit is van belang dat sekere eienskappe van die pressorstof ooreenstem met dié van 'n bekende peptied en kragtige vasokonstriktor, naamlik angiotensien II (Ang II). Ang I word deur die proteolitiese ensiem, renien, uit 'n groter peptied vrygestel deur sekere granulêre selle in die nier en word dan in die longe tot die vasokonstriktor Ang II geprosesseer. Bewyse van renienaktiwiteit is reeds deur verskeie navorsers in die hartspier gevind (veral in die regteratrium) en ons kon Ang II in konsentrasies van ongeveer $7 \mathrm{pmol} / \mathrm{g}$ vars weefsel in die regter 
atrium van konyne met behulp van radioimmuunbepalings lokaliseer. Hierdie vlak van Ang II is waarskynlik te laag om arteriële bloeddruk noemenswaardig te beinvloed. Dit is egter nog te vroeg om te sê of AT inderdaad Ang II of moontlik 'n naverwante verbinding is. Daar kan in hierdie stadium ook nie gesê word of AT (of sy prohormoon) in die SAG gelokaliseer is nie.

2. In 1981 het Kanadese navorsers ${ }^{6}$ gevind dat ruekstrakte van rotatriumspier die verdere unieke eienskap besit dat dit 'n verhoogde uitskeiding van uriene (diurese), tesame met elektroliete, veral natrium (natriurese) veroorsaak. Kort hierna is aangetoon dat atriumekstrakte ook vaatverslappend kan inwerk. Hierdie waarneming het gelei tot ' $n$ vloedgolf van navorsing in verskeie oorsese laboratoria en indrukwekkende vordering met die karakterisering en sintesebeheer van die sg. atriale natriuretiese peptiede (ANP) is reeds gemaak, en die belangrikste bevindings is in verskeie oorsigartikels opgesom. ${ }^{7,8}$

Die aktiewe natriuretiese peptied wat in mensatrium gevind word, is $\alpha$-hANP, wat bestaan uit 28 aminosure en die karboksiterminaal van $\mathrm{sg} \beta$ - en $\gamma$-peptiede is. Hierdie peptiede word intrasellulêr uit 'n preprohormoon (152 aminosure) gevorm. Verskeie kliniese studies met $\alpha$-hANP is reeds uitgevoer. So is, byvoorbeeld, gevind ${ }^{9}$ dat toediening van $\alpha$-hANP aan volwasse manlike vrywilligers gelei het tot 'n twee- tot drievoudige toename in diurese, natriurese en 'n geringe daling in sistoliese en diastoliese bloeddruk, maar uitskeiding van kalium is nie beinvloed nie. Plasmavlakke van $\alpha$ hANP was betekenisvol hoër in pasiënte met kongestiewe hartversaking as in normale kontroles. ${ }^{9}$ Laasgenoemde, en ander resultate, het gelei tot die suggestie dat 'n toename in ekstraselullêre vogvolume die belangrikste prikkel vir die sekresie van $\alpha$-hANP in die algemene bloedsirkulasie is.

Alhoewel verdere intensiewe navorsing klaarblyklik noodsaaklik is, is dit geregverdig om in hierdie stadium te postuleer dat die atriumspier twee peptiedsisteme bevat, naamlik pressorpeptiede sonder natriuretiese aktiwiteit, en natriuretiese hormone met geringe depressoreffekte. Die hart, en spesifiek die atriumspier, is ongetwyfeld 'n aktiewe endokriene orgaan.

J.J. Theron

Departement Fisiologie, Universiteit van Pretoria, Posbus 667, Pretoria 0001

\section{VERWYSINGS}

1. Theron, J.J., Biagio, R., Meyer, A.C. \& Boekkooi, S. (1978). Ultrastructural observations on the maturation and secretion of granules in atrial myocardium, J. Molec. Cell. Cardiol., 10, $567-592$.

2. Theron, J.J., Biagio, R. Meyer, B.J. \& Viljoen, C.C. (1980). Die moontlike rol van atriumgranules in die handhawing van bloeddruk, Geneeskunde, 22, 255-259.

3. Theron, J.J., Biagio, R., Meyer, A.C., Boekkooi, S. \& Seegers, J.C. (1978). The effect of a serotonin inhibitor on the serotonin content and ultra-structrure of rat atria and ventricles with special reference to atrial granules, Life Sci., 23, 111-120.

4. Nieuwenhuis, J.J., Labuschagne, B.C., Theron, J.J. \& Biagio, R. (1984). Cardiac substances that influence blood pressure. 1 . Identification of the agent that lowers blood pressure in anaesthetized rats, Biochem. Biophys. Res. Comm., 125, $1074-1081$.

5. Nieuwenhuis, J.J. \& Theron, J.J. (1985). Cardiac substances that influence blood pressure. II. Potent pressor activity in rat and rabbit atrial muscle, Biochem. Biophys. Res. Comm., 129, 472-478.

6. De Bold, A.J., Borenstein, H.B. Veress, R.T. \& Sonnenberg, H. (1981). A rapid and potent natriuretic response to intravenous injection of atrial myocardial extract in rats, Life Sci., 28, 89-94.

7. Redaksioneel (1984). Atrial natriuretic peptides, Lancet, 2 , 328-329.

8. Rosendorff, C. (1985). Atrial natriuretic peptides, $S$ A Mediese Tydskrif, 67, 354.

9. Tikkanen, I., Metsärinne, K., Fyhrquist, F. \& Leidenhuis, R. (1985). Plasma atrial natriuretic peptide in cardiac disease and during infusion in healthy volunteers, Lancet, 2, 66-69.

\section{VERKLARINGS}

\begin{tabular}{|c|c|}
\hline $\begin{array}{l}\text { Atriumspier } \\
\text { Diureties }\end{array}$ & $\begin{array}{l}\text { - die spier van die voorkamers van die hart. } \\
\text { - 'n verhoogde uitskeiding van uriene per } \\
\text { tydseenheid. }\end{array}$ \\
\hline Eksositose & $\begin{array}{l}\text { - 'n meganisme waardeur sekere selle hul } \\
\text { produkte sekreteer. }\end{array}$ \\
\hline Endokriene orgaan & $\begin{array}{l}\text { - 'n orgaan (klier) wat direk in die bloed } \\
\text { sekreteer en daardeur die funksie van sekere } \\
\text { teikenselle beinvloed. }\end{array}$ \\
\hline Endositose & $\begin{array}{l}\text { - sellulere opname van stowwe deur 'n sel uit } \\
\text { die vloeistof wat 'n sel omring. }\end{array}$ \\
\hline Golgikompleks & $\begin{array}{l}\text { - 'n intrasellulêre struktuur wat veral by die } \\
\text { finale voorafbereiding van sintetiese pro- } \\
\text { dukte van die sel vir sekresie betrokke is. }\end{array}$ \\
\hline Granules & $\begin{array}{l}\text { - intrasellulêre strukture wat omring is deur } \\
\text { 'n membraan en gewoonlik 'n granulêre in } \\
\text { houd het. }\end{array}$ \\
\hline Natriureties & $\begin{array}{l}\text { - verhoogde uitskeiding van natrium in die } \\
\text { uriene. }\end{array}$ \\
\hline Renienaktiwiteit & $\begin{array}{l}\text { - 'n aanduiding van die vlak (konsentrasie), } \\
\text { van die proteolitiese ensiem, renien, in } \\
\text { bloed of weefsels. }\end{array}$ \\
\hline Reseptorproteiene & $\begin{array}{l}\text { - proteiene wat weens hul struktuur en vorm } \\
\text { ander soortgelyke proteiene (byvoorbeeld } \\
\text { hormone) "herken" en met hulle verbind } \\
\text { om spesifieke selreaksies te inisieer. }\end{array}$ \\
\hline Siroplasma & $\begin{array}{l}\text { - die plasma of algemene grondstof van ' } \mathrm{s} \\
\text { sel. }\end{array}$ \\
\hline Vasokonstriktor & $\begin{array}{l}\text { - 'n stof wat spasme (konstriksie) van sekere } \\
\text { bloedvate veroorsaak. }\end{array}$ \\
\hline Ventrikelspier & $\begin{array}{l}\text { - die spier van die kamers (pompkamers) var } \\
\text { die hart. }\end{array}$ \\
\hline
\end{tabular}

